\title{
SOLUBILITY OF CARBON, MANGANESE AND SILICON IN $\alpha$-IRON OF Fe-Mn-Si-C ALLOYS
}

\author{
(iD)Natalia Filonenko ${ }^{a, b}, *$, Alexander Babachenko ${ }^{\mathbf{b}}$, Ganna Kononenko $^{\mathbf{b}}$, Ekaterina Domina $^{\mathbf{b}}$ \\ ${ }^{a}$ State Institution "Dnipropetrovsk Medical Academy of the Ministry of Health of Ukraine" \\ 9, Vernadsky Str., Dnipro, 49044, Ukraine \\ ${ }^{b}$ Z.I. Nekrasov Iron and Steel Institute of National Academy of Sciences of Ukraine \\ 1, Akademika Starodubova Square, Dnipro, 49107, Ukraine \\ *Corresponding Author: natph2016@gmail.com \\ Received August 18, 2020; revised October 12, 2020; accepted October 13, 2020
}

The study was performed on alloys with a carbon content of $0.37-0.57 \%$ (wt.), silicon $0.23-0.29 \%$ (wt.), manganese $0.7-0.86 \%$ (wt.), the rest - iron. To determine the phase composition of alloys used microstructural, microanalysis and X-ray analysis. In addition, the physical characteristics of the alloys studied in this paper were determined, such as alloy chemical dependence of extension and contraction ratio, impact toughness and hardness. The results obtained in this paper showed that the iron-based alloy with the content of carbon of $0.57 \%$ (wt.), silicon of $0.28 \%$ (wt.) and manganese of $0.86 \%$ (wt.)) had the superior microstructure and physical properties. It was determined that after a number of crystallization and phase transformation the alloy phase structure includes two phases: $\alpha$-iron and cement magnesium dopingFe ${ }_{2 .} \mathrm{Mn}_{0,3} \mathrm{C}$. For the first time using the method quasi-chemistry received an expression of the free energy of a solid solution $\alpha$-iron alloyed with silicon and magnesium, and determined the solubility limit of carbon, manganese and silicon. In $\delta$-iron may dissolve to $0.09 \%$ (wt.) carbon, manganese up to $3.5 \%$ (wt.), silicon - $0.25 \%$ (wt.). The maximum content in $\alpha$-iron can reach: carbon - $0.017 \%$ (wt.), manganese - $21 \%$ (wt.), silicon - $1.3 \%$ (wt.).

KEY WORDS: Fe-Mn-Si-C alloys, solubility limit of carbon, manganese, silicon in $\alpha$-iron

As is known, there is currently a special interest in steels that have high strength and ductility. To increase the complex of mechanical properties in an economical way using alloying of alloys based on iron with manganese and silicon [1].

In the al loys of the Fe-Mn-Si-C system during the crystallization of the melt, the primary phase may be $\delta$ - iron with a carbon content of up to $0.2 \%$ (wt.), manganese up to $2 \%$ (wt.) and silicon up to $1 \%$ (wt.). During the crystallization of alloys of the Fe-Mn-Si-C system, successive transformations of peritectic were observed: $\mathrm{L} \rightarrow \mathrm{L}+\delta \rightarrow \delta+\gamma \rightarrow \gamma$ [2-5]. It is known that doping alloys based on iron with manganese and silicon has almost no effect on the temperature of point $\mathrm{A}_{1}$ and shifts point $\mathrm{S}$ (eutectoid point on the equilibrium phase diagram of the $\mathrm{Fe}-\mathrm{C}$ system) to a low carbon content, which leads to an increase in the volume fraction of perlite in the microstructure [6].

According to the results presented in [7-10], the solubility of carbon in ferrite is in the alloys of the Fe-C system - 0.095\% (at.), Mn-C - 6\% (at.), silicon Fe-Si - 10-18.5\% (at.), Mn-Si - 18.5-10\% (at.) in dependence from temperature. In the ternary system Fe-Mn-C are the solubility of carbon and manganese in $\alpha$-iron at temperatures $505-971 \mathrm{~K}$ [4]. In this paper it is noted that at a temperature of $505 \mathrm{~K}$ the content of carbon in $\alpha$-iron was $4 \cdot 10^{-9} \%$ (wt.), and manganese $-0.5 \%$ (wt.). The authors of [7] note that in the alloys of the Fe-Mn-Si-C system is the consistent formation of solid solutions, the carbon content of which is more than $0.08 \%$ (wt.). Thermodynamic databases (ThermoCalc, FactSage, MTDat, PANDAT, JMatPro, IDS and CALPHAD) are currently widely used in steel and alloy research, development of new materials and production technologies in the metallurgical industry, but the reliability of forecasts made with these programs is limited by the accuracy of thermodynamic data. Some experimental data, which are important for multicomponent systems, are quite old and insufficiently tested by modern experimental methods [11]. As is known, to predict the phase composition of alloys and phase transformations plays an important role solubility limit of the alloying elements in alloys.

The aim of this work was to determine the solubility limits of carbon, silicon and manganese in $\alpha$-iron alloys of the Fe-Mn-Si-C system.

\section{MATERIALS AND METHODS}

Research carried out on alloys containing carbon $0.37-0.57 \%$ (wt.), silicon $0.23-0.29 \%$ (wt.), manganese $0.7-0.86 \%$ (wt.), the rest - iron. The smelting of alloys of the Fe-Mn-Si-C system was performed in a furnace in alundum crucibles in an argon atmosphere. The cooling rate of the alloys after casting was $10 \mathrm{~K} / \mathrm{s}$. Metallographic sections of Fe-Mn-Si-C alloys were made according to standard methods using diamond pastes. Chemical and spectral analysis were used to determine the chemical composition of the alloy [11]. The phase composition of the alloys was determined using an optical microscope "Neofot-21". The main results of micro-X-ray spectral analysis were obtained using an electron microscope JSM-6490 with a scanning attachment ASID-4D and energy-dispersive X-ray microanalyzer "LinkSystems 860" with software. X-ray diffraction analysis was performed on a DRON-3 diffractometer in monochromatized $\mathrm{Fe}-\mathrm{K} \alpha$ radiation. 


\section{RESULTS AND DISCUSSION}

The microstructure of the alloy with the carbon content of $0.37 \%$ (wt.), silicon $0.23 \%$ (wt.), manganese $0.86 \%$ (wt.) in the cast, state is represented by ferrite and perlite (Fig. 1a).
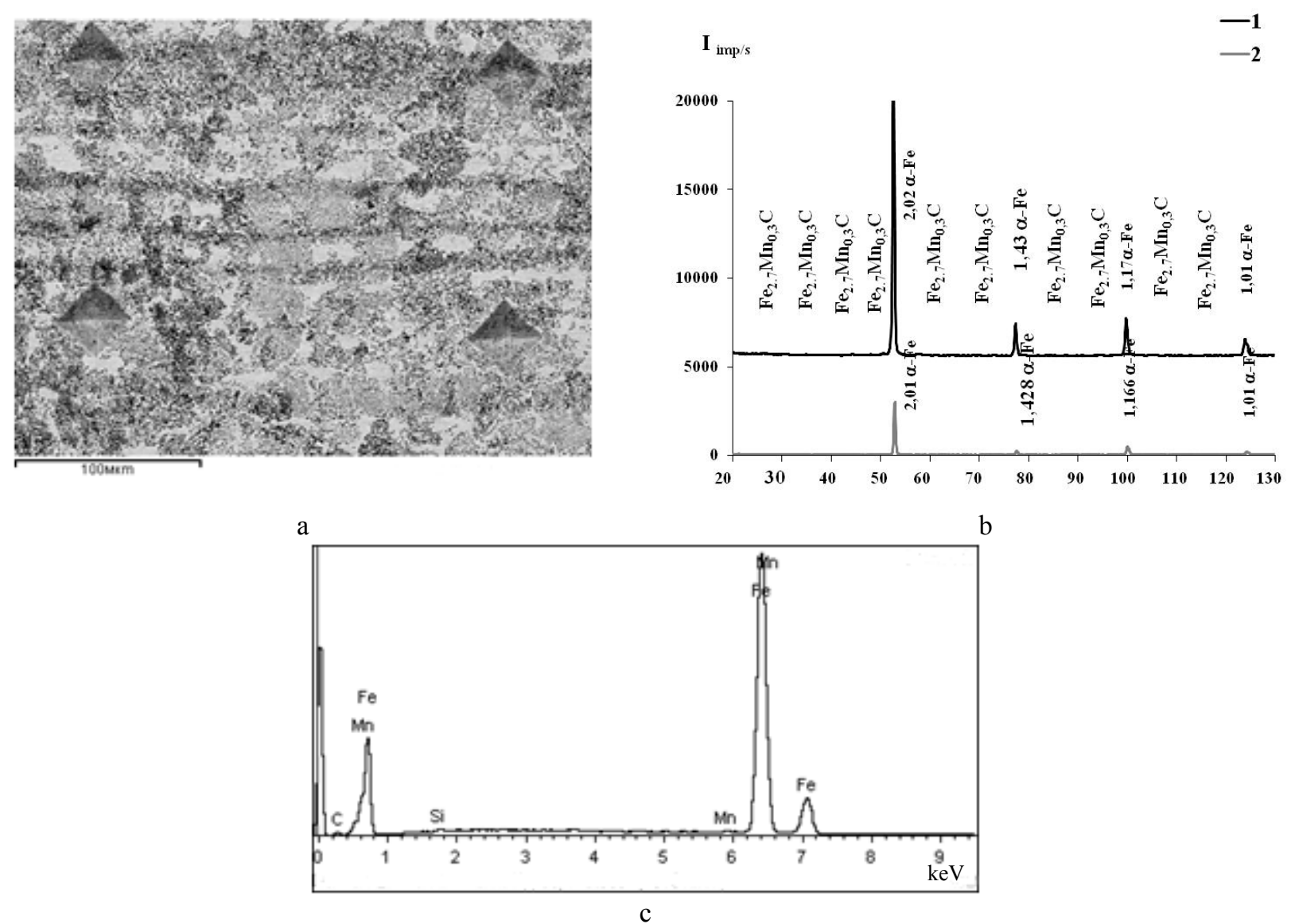

Figure 1. Alloy based on iron with a carbon content of $0.45 \%$ (wt.), silicon $0.23 \%$ (wt.), manganese $0.86 \%$ (wt.) in the cast state: a) microstructure, $\times 800$, b) diffraction pattern $(1-\alpha$-iron of Fe-Mn-Si-C alloy, $2-\alpha$-iron in Fe-C alloy), c) micro-X-ray spectral analysis curve

The results of X-ray analysis in this alloy were discovered only two phases - ferrite and carbide (Fig. 1b). Carbide, as a structural component of perlite, was presented in these alloys of the Fe-Mn-Si-C phase $\mathrm{Fe}_{2.7} \mathrm{Mn}_{0,3} \mathrm{C}$. It should be noted that perlite has two colors after surface etching of the samples with sodium pirate - light and dark. In perlite light $\mathrm{r}$ color content of manganese $-0.37 \%$ (wt.), silicon - 0,38\% (wt.). In perlite dark color high content of alloying elements: manganese $-0.79 \%$ (wt.), silicon $-0.41 \%$ (wt.). Thus, the results make it possible to assert that in alloys formed a reason region richest manganese and silicon.

On the diffraction pattern, the $\alpha$-iron lines were shifted toward larger angles compared to pure $\alpha$-iron. The obtained result can be explained by the fact that the ferrite is doped with manganese and silicon and the ferrite lattice parameter changes. According to the results of micro-X-ray spectral analysis in ferrite, the manganese content was $1.27 \%$ (wt.), silicon $-0.27 \%$ (wt.).

As Table shows, the characteristics of strength and hardness for all the alloys are high, and for the alloy containing carbon $-0.57 \%$ (wt.), silicon $-0.28 \%$ (wt.) and manganese $-0.86 \%$ (wt.), plasticity and fracture toughness are higher as compared to those for the other alloys that are used in the manufacture of railway wheels.

Table.

Dependence of the extension andcontraction ratio, impact toughness and hardness on the chemical composition

\begin{tabular}{|c|c|c|c|c|}
\hline $\begin{array}{c}\text { Content of chemical elements in } \\
\text { alloys, \% (wt.) }\end{array}$ & $\begin{array}{c}\text { Relative extension } \\
\text { n, } \delta, \%\end{array}$ & $\begin{array}{c}\text { Relative } \\
\text { contraction } \psi, \%\end{array}$ & $\begin{array}{l}\text { Impact toughness, } \\
\mathrm{KCU} U_{\text {obed }}, \mathrm{J} / \mathrm{cm}^{2}\end{array}$ & $\begin{array}{l}\text { Hardness, } \\
\text { HB }\end{array}$ \\
\hline $\mathrm{C}=0.37 ; \mathrm{Si}=0.23 ; \mathrm{Mn}=0.75$ & 8 & 17 & 34 & 324 \\
\hline $\mathrm{C}=0.57 ; \mathrm{Si}=0.28 ; \mathrm{Mn}=0.86$ & 11 & 25 & 40 & 341 \\
\hline
\end{tabular}

A quasi-chemical method was used to determine the solubility of carbon, silicon, and manganese in the $\delta$ - and $\alpha$ iron of Fe-Mn-Si-C alloys. 
The structure of ferrite has a volume-centered lattice and belongs to the spatial group $O_{h}^{9}-\operatorname{Im} 3 \mathrm{~m}$ with 8 atoms in the first coordination sphere [12]. Each atom of the BCC lattice has six tetrahedral and three octahedral pores. Of the six atoms surrounding the octahedral pore, two are closest to the others [14]. The arrangement of carbon atoms in the BCC lattice can be described as follows: the arrangement of carbon atoms in the octahedral pore, which have four nearest metal atoms at a distance of $2.02 \AA$, and two at a distance of $1,43 \AA$, each metal atom has 8 neighbors, which are located on distances of $2,48 \AA$ from each other.

To obtain the calculated results of the solubility limit of carbon atoms in the ferrite lattice, a quasi-chemical method was used, taking in ti account data on the position of carbon in a solid solution of $\alpha$-iron [13].

The interaction of $\mathrm{Fe}-\mathrm{Fe}, \mathrm{Fe}-\mathrm{C}, \mathrm{Fe}-\mathrm{Si}, \mathrm{Fe}-\mathrm{Mn}$ and $\mathrm{Fe}-\mathrm{V}$ atoms, where $\mathrm{V}$ is a vacancy can become side red as follows: the interaction energies of atomic pairs $v_{\mathrm{FeFe}}, v_{\mathrm{FeS}}, v_{\mathrm{FeV}}, v_{\mathrm{FeC}}, v_{\mathrm{FeMn}}$ and $v_{\mathrm{MnC}}$. The results presented in [14-15] were used for numerical values of the interaction energy of pairs of atoms.

The free energy of ferrite can be determined by the formula: $\mathrm{F}=E-k T \ln W$, where $\mathrm{E}$ is the internal energy of ferrite, $W$ is the thermodynamic probability of the placement of atom is the nodes of the crystal lattice of ferrite, $\mathrm{k}=1,38 \cdot 10^{-23} \mathrm{~J} / \mathrm{K}-$ Boltzmann constant, $\mathrm{T}-$ absolute temperature. Thus, the free energy of ferrite is determined as follows:

$$
\begin{aligned}
& F=-8\left(N_{F e} N_{C} v_{F e C}+N_{M n} N_{C} v_{M n C}+N_{S i} N_{C} v_{S i C}+N_{F e} N_{V} v_{F e V}+N_{M n} N_{V} v_{M n V}+N_{S i} N_{V} v_{S i V}\right)- \\
& -k T\left(8\left(N_{F e}+N_{M n}+N_{S i}\right)\left(\ln \left(N_{F e}+N_{M n}+N_{S i}\right)-1\right)-\right. \\
& -8 N_{F e}\left(\ln N_{F e}-1\right)-8 N_{M n}\left(\ln N_{M n}-1\right)-8 N_{S i}\left(\ln N_{S i}-1\right)+ \\
& +\left(N_{C}+N_{V}\right)\left(\ln \left(N_{C}+N_{V}\right)-1\right)-N_{C}\left(\ln N_{C}-1\right)-N_{V}\left(\ln N_{V}-1\right)
\end{aligned}
$$

To calculate the solubility of carbon in $\alpha$-iron, wended it find the solution of the system of equations:

$$
\frac{\partial F}{\partial N_{C}}=0, \frac{\partial F}{\partial N_{V}}=0, \frac{\partial F}{\partial N_{S i}}=0, \frac{\partial F}{\partial N_{M n}}=0, \frac{\partial F}{\partial N_{F e}}=0
$$

The resulting system of equations (2) is transcendental. Usually the solution of such equations can be obtained graphically or numerically. But in the framework of this problem it is expedient to consider an asymptotic solution of the equations. For this we present the logarithm included in each of the equations of the system (1) in the form of Taylor series (this is acceptable in case of its convergence):

$$
\begin{aligned}
& \frac{\partial F}{\partial N_{C}}=-8 N_{F e} v_{F e C}-8 N_{M n} v_{M n C}-8 N_{S i} v_{S i C}-k T\left(\ln N_{V}+\sum_{n=1}^{\infty} \frac{(-1)^{n+1}}{n}\left[\frac{N_{C}^{n}}{N_{V}^{n}}-\left(N_{C}-1\right)^{n}\right]\right)=0 \\
& \frac{\partial F}{\partial N_{V}}=-8 N_{F e} v_{F e V}-8 N_{M n} v_{M n V}-8 N_{S i} v_{S i V}-8 k T\left(\ln N_{C}+\sum_{n=1}^{\infty} \frac{(-1)^{n+1}}{n}\left[\frac{N_{V}^{n}}{N_{C}^{n}}-\left(N_{V}-1\right)^{n}\right]\right)=0 \\
& \frac{\partial F}{\partial N_{F e}}=-8 N_{C} v_{F e C}-8 N_{V} v_{F e V}-8 k T\left(\ln \left(N_{M n}+N_{S i}\right)+\sum_{n=1}^{\infty} \frac{(-1)^{n+1}}{n}\left[\frac{N_{F e}^{n}}{\left(N_{M n}+N_{S i}\right)^{n}}-\left(N_{F e}-1\right)^{n}\right]\right)=0 \\
& \frac{\partial F}{\partial N_{M n}}=-8 N_{C} v_{M n C}-8 N_{V} v_{M n V}-8 k T\left(\ln \left(N_{F e}+N_{S i}\right)+\sum_{n=1}^{\infty} \frac{(-1)^{n+1}}{n}\left[\frac{N_{M n}^{n}}{\left(N_{F e}+N_{S i}\right)^{n}}-\left(N_{M n}-1\right)^{n}\right]\right)=0 \\
& \frac{\partial F}{\partial N_{S i}}=-8 N_{C} v_{S i C}-8 N_{V} v_{S i V}-8 k T\left(\ln \left(N_{M n}+N_{F e}\right)+\sum_{n=1}^{\infty} \frac{(-1)^{n+1}}{n}\left[\frac{N_{S i}^{n}}{\left(N_{M n}+N_{F e}\right)^{n}}-\left(N_{S i}-1\right)^{n}\right]\right)=0
\end{aligned}
$$

To obtain an asymptotic estimate of system (2) solution it is sufficient to consider the first two terms of expansion in the logarithm expanding.

There sults of solving the system of equations showed that up to $0.09 \%$ (wt.) of carbon, manganese up to $3.5 \%$ (wt.), silicon $-0.25 \%$ (wt.) can be dissolved in $\delta$-iron. The obtained result regarding the carbon content in $\delta$-iron is consistent with the results of [16-17].

The maximum solubility of elements in $\alpha$-iron is: carbon $-0.017 \%$ (wt.), manganese $-15 \%$ (wt.), silicon - 1.3\% (wt.), which is consistent with the results presented in [3].

Thus, the maximum solubility of carbon, manganese and silicon in $\alpha$-iron alloys of the Fe-Mn-Si-C system have lower numerical values compared it the insolubility in the corresponding binary systems. The obtained results can be explained by the fact that there placement of iron atoms by manganese and silicon atoms in the $\alpha$-iron lattice ads it the deformation of the lattice, which affects the solubility of carbon [14]. 


\section{CONCLUSION}

The analysis phase composition in the studied alloys Fe-C-Mn-Si containing carbon $0.37-0.57 \%$ (wt.), silicon $0.23-29 \%$ (wt.), manganese $0.7-0.86 \%$ (wt.), the rest - iron. It is determined that after crystallization and a number of phase transformations the microstructure of the alloy consists of $\alpha$-iron and manganese-doped cementite $\mathrm{Fe}_{2.7} \mathrm{Mn}_{0.3} \mathrm{C}$. In the structure of alloys the reason uneven distribution of alloying elements - there are areas of perlite enriched manganese and silicon. For the first time, depending on the free energy of a solid solution of $\alpha$ - and $\delta$-iron doped with silicon and manganese, a quasi-chemical method was obtained and the solubility limits of carbon, manganese and silicon were determined. Up to $0.09 \%$ (wt.) of carbon, manganese up to $3.5 \%$ (wt.), silicon $-0.25 \%$ (wt.) can be dissolved in $\delta$-iron. The maximum content in $\alpha$-iron can reach carbon $-0.017 \%$ (wt.), manganese $-21 \%$ (wt.), silicon - $1.3 \%$ (wt.).

It was found that the maximum solubility of carbon, manganese and silicon in $\alpha$-iron of Fe-Mn-Si-C alloys have lower numerical values compared it the insolubility in the corresponding binary systems.

The work was performed within the specific project "Resurs" KC063.18 "Development of chemical composition and technological decisions for the manufacture of railway wheels for different application and their maintainability" of the NAS of Ukraine.

\section{ORCID IDs}

(D)Natalia Yu. Filonenko, https://orcid.org/0000-0003-1219-348X;

(D)Alexander Babachenko, https://orcid.org/0000-0003-4710-0343;

\section{REFERENCES}

[1] Z. Zongy, and S. Rolf, Journal of Alloys and Compounds, 363, 202 (2004), https://doi.org/10.1016/S0925-8388(03)00462-6.

[2] P. Presoly, G. Xia, P. Reisinger, and C. Bernhard, Berg Huettenmaenn Monatsh, 159, 430 (2014), https://doi.org/10.1007/s00501-014-0306-5

[3] J. Miettinen, V.-V. Visuri, and T. Fabritius, Thermodynamic description of the Fe-Al-Mn-Si-C system for modelling solidification of steels, Acta Universitatis Ouluensis C Technica, 704, (University of Oulu, Finland, 2019). pp. 242, http://jultika.oulu.fi/files/isbn9789526222516.pdf.

[4] D. Djurovic, B. Hallstedt, J. Appen, and R. Dronskowski, Calphad, 35(4), 479 (2011). https://doi.org/10.1016/j.calphad.2011.08.002.

[5] W.S. Zheng, X.G. Lu, Y.L. He, and L. Li, J. Iron Steel Res. Int. 24, 190 (2017), https://doi.org/10.1016/S1006706X(17)30027-4

[6] P. Głowacz, M. Tenerowicz-Żaba, M. Sułowski, and J. Konstanty, International Journal "NDT Days”, II(3), 300 (2019), https://www.bg-s-ndt.org/journal/vol2/JNDTD-v2-n3-a08.pdf.

[7] O.A. Bannykh, and M.E. Drytsa, Диаграммы состояния двойных и многокомпонентных систем на основе железа [Рhаsе Diagrams of Binary and multicomponent Systems based on of the iron: Handbook] (Metallurgiya, Moscow, 1986), pp. 439. (in Russian)

[8] N.P. Lyakishev, Диаграммы состояния двойных металлических систем: Справочник [Phase Diagrams of Binary Metal Systems: Handbook], (Mashinostroenie, Moscow, 2001), pp. 498. (in Russian)

[9] E.G. Hoel, in: Infacon VII, (Trondheim, Norway, 1995), pp. 601, https://www.pyrometallurgy.co.za/InfaconVII/601-Hoel.pdf.

[10] I. Ohnuma, Sh. Abe, Sh. Shimenouchi, T. Omori, R. Kainuma, and K. Ishida, ISIJ International, 52(4), 540 (2012). https://doi.org/10.2355/isijinternational.52.540.

[11] P. Presoly, J. Six, and C. Bernhard, Materials Science and Engineering, 119, 012013-1 (2016). https://doi.org/10.1088/1757899X/119/1/012013.

[12] S.V. Tverdokhlebova, Visnyk Dnipropetrovskogo nacionalnogo universytetu, serija Fizyka, Radioelektronika, 14(12/1), 100-104 (2007), http://www.vdnu.narod.ru/v14/pdf/s26_14.pdf. (in Ukrainian)

[13] M.P. Shaskolskaya, Кристаллография [Crystallography], (Vyisshayashkola, Moscow, 1984), pp. 376. (in Russian)

[14] E. Vincent, C.S. Becquart, and C. Domain, Journal of Nuclear Materials, 351, 88 (2006). https://doi.org/10.1016/j.jnucmat.2006.02.018.

[15] N.Yu. Filonenko, O.S. Baskevych, V.V. Soboliev, Naukovyi Visnyk Natsionalnoho Hirnychoho Universytetu, 4, 74 (2012), http://nv.nmu.org.ua/index.php/ru/component/jdownloads/finish/34-04/528-2012-4-filonenko/0. (in Ukrainian)

[16] S.Y.P. Allain, S. Gaudez, G. Geandier, J.C. Hell, M. Gouné, F. Danoix, M. Soler, S. Aoued, and A. Poulon-Quintin, Mater. Sci. Eng. A, 710, 245 (2018), https://doi.org/10.1016/j.msea.2017.10.105.

[17] Y.P. Sébastien, S. Aoued, A. Quintin-Poulon, M. Gouné, F. Danoix, J. Hell, M. Bouzat, and M. Soler, Materials, 11(7), 1087 (2018), https://doi.org/10.3390/ma11071087

\section{РОЗЧИННІСТЬ ВУГЛЕЦЮ, МАРГАНЦЮ ТА КРЕМНІЮ У $\alpha$-ЗАЛІЗІ СПЛАВІВ СИСТЕМИ Fe-Mn-Si-C}

Н.Ю. Філоненко ${ }^{\text {a,b }}$, О.І. Бабаченко ${ }^{\text {, Г. Г. Кононенко }}{ }^{\text {, К.Г. К. Дьоміна }}{ }^{b}$

аДЗ «Дніпропетровська державна медична академія МОЗ Украӥни»

49044, Україна, м. Дніпро, вул. Володимира Вернадського, 9

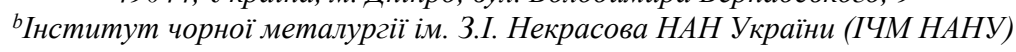

49107, Україна, м. Дніпро, пл. Ак. Стародубова К.Ф., 1

Дослідження проводили на сплавах 3 вмістом вуглецю 0,37-0,57 \% (мас.), кремнію 0,23-0,29 \% (мас.), марганцю 0,7-0,86\% (мас.), решта - залізо. Для визначення фазового складу сплавів використовували мікроструктурний, мікрорентгеноспектральний та рентгеноструктурний аналізи. В роботі були визначені фізичні характеристики сплавів, що досліджували в даній роботі, а саме, залежність відносного видовження, відносного звуження, ударної в'язкості та твердості 
від хімічного складу сплаву. Отримані в даній роботі результати показали, що найкращі мікроструктурні та фізичні характеристики має сплав на основі заліза з вмістом вуглецю 0,57 \% (мас.), кремнію 0,28 \% (мас.), марганцю 0,88 \% (мас.). Визначено, що після кристалізації та низки фазових перетворень фазовий склад сплаву представлений двома фазами: $\alpha$-залізом та легованим марганцем цементитом $\mathrm{Fe}_{2.7} \mathrm{Mn}_{0,3} \mathrm{C}$. Крім цього, в мікроструктурі сплаву існують ділянки фериту збагачені марганцем та кремнієм. Вперше з застосуванням квазіхімічного методу отримали залежність вільної енергії твердого розчину $\alpha$-заліза, легованого кремнієм та марганцем, та визначили межу розчинності вуглецю, марганцю та кремнію. В $\delta$-залізі може розчинятись до $0,09 \%$ (мас.) вуглецю, марганцю до 3,5 \% (мас.), кремнію - 0,25\% (мас.). Максимальний вміст в $\alpha$-залізі може досягати: вуглецю - 0,017 \% (мас.), марганцю - 21 \% (мас.), кремнію - 1,3 \% (мас.).

КЛЮЧОВІ СЛОВА: сплави Fe-Mn-Si-C, межа розчинності, вуглець, марганець, кремній, $\alpha$-залізо

РАСТВОРИМОСТЬ УГЛЕРОДА, МАРГАНЦА И КРЕМНИЯ В $\alpha$-ЖЕЛЕЗЕ СПЛАВОВ СИСТЕМЫ Fe-Mn-Si-C

Н.Ю. Филоненко ${ }^{\text {a,b }}$, А.И. Бабаченко ${ }^{\text {, А.А.Кононенко }}$, К.Г. Дьомина ${ }^{b}$

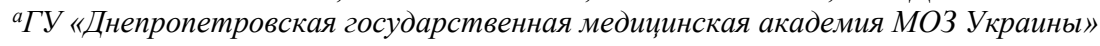

49044, Украина, г. Днепр, ул. Владимира Вернадского, 9

${ }^{b}$ Институт черной металлургии им. З.И. Некрасова НАН Украины (ИЧМ НАНУ)

49107, Украина, г. Днепр, ул. Ак. Стародубова К.Ф., 1

Исследования проводились на сплавах с содержанием углерода 0,37-0,57 \% (мас.), кремния 0,23-0,29 \% (мас.), марганца 0,7-0,86 \% (мас.), остальные - железо. Для определения фазового состава сплавов использовали микроструктурный, микрорентгеноспектральный и рентгеноструктурный анализы. В работе были определены физические характеристики сплавов, которые исследовали в данной работе, а именно, зависимость относительного удлинения, относительного сужения, ударной вязкости и твердости от химического состава сплава. Полученные в данной работе результаты показали, что лучшие микроструктурных и физические характеристики имеет сплав на основе железа с содержанием углерода 0,57\% (мас.), кремния 0,28 \% (мас.), марганца 0,88 \% (мас.). Определено, что после кристаллизации и ряда фазовых превращений фазовый состав сплава представлен двумя фазами: $\alpha$-железом и легированным марганца цементитом $\mathrm{Fe}_{2.7} \mathrm{Mn} 0,3 \mathrm{C}$. Кроме этого, в микроструктуре сплава существуют участки феррита, обогащенные марганца и кремния. Впервые с применением квазихимического метода получили зависимость свободной энергии твердого раствора $\alpha$-железа, легированного кремния и марганца, и определили границу растворимости углерода, марганца и кремния в нем. В $\delta$-железе может растворяться до 0,09 \% (мас.) углерода, марганца до 3,5 \% (мас.), кремния - 0,25\% (мас.). Максимальное содержание в $\alpha$-железе может достигать: карбона - 0,017\% (масс.), марганца - $21 \%$ (масс.), кремния - 1,3 \% (масс.).

КЛЮЧЕВЫЕ СЛОВА: сплавы Fe-Mn-Si-C, предел растворимости, углерод, марганец, кремний, $\alpha$-железо 